\title{
Influência de Prebióticos Na Fermentação de Extrato Hidrossolúvel de Soja Verde
}

Carolina Battistini (I), Fernanda Chiarella (I), Erica Sayuri Ichimura

(I), Eliana Paula Ribeiro (I), Leo Kunigk (I), José Ubirajara Vieira Moreira (II), Cynthia Jurkiewicz Kunigk (I)

(I) IMT - Instituto Mauá de Tecnologia (Praça Mauá 01, São Caetano do Sul, SP, Brasil), (II) EMBRAPA Soja - Empresa Brasileira de Pesquisa Agropecuária (Londrina, PR, Brasil)

\section{Resumo}

A soja verde (Glycine Max (L.) Merril) é colhida quando os grãos estão imaturos, possui maior teor de umidade, amido, sacarose e menor teor de oligossacarídeos, rafinose e estaquiose. Bebidas fermentadas produzidas com extrato de soja estão disponíveis no mercado mundial há muitos anos, entretanto pouco se conhece sobre a fermentação de extrato de soja verde. Considerando os benefícios funcionais e sensoriais da soja verde, este trabalho teve como objetivo avaliar o desenvolvimento e sobrevivência de bactérias probióticas e Streptococcus thermophilus em extrato hidrossolúvel de soja verde com adição de prebióticos. Foram utilizadas duas variedades de soja verde, (Veggie, China e BRS 232 Embrapa, Brasil). Para a obtenção do extrato hidrossolúvel com 3,0 \% de proteínas, $300 \mathrm{~g}$ de grãos de soja verde congelados foram macerados em 1,0 L de água fervente por 5 minutos e a água descartada. Os grãos foram triturados com água, na proporção mássica de 3:7 e o extrato separado por filtração. Para a fermentação, foi adicionado ao extrato, $8,0 \%$ de frutooligossacarídeo (FOS) ou inulina e a cultura composta por Lactobacillus acidophillus La-5, Bifidobacterium animalis Bb-12 e Streptococcus thermophilus. Os extratos, com pH inicial de 6,5 , foram incubados a $37^{\circ} \mathrm{C}$ até que o pH atingisse 4,8 e após a fermentação foram armazenados a $5{ }^{\circ} \mathrm{C}$. Como controles, foram fermentados os extratos sem prebióticos. Os experimentos foram realizados em duplicata e analisados por ANOVA. O

\footnotetext{
Referência:

Carolina Battistini, Fernanda Chiarella, Erica Sayuri Ichimura, Eliana Paula Ribeiro, Leo Kunigk, José Ubirajara Vieira Moreira, Cynthia Jurkiewicz Kunigk.Influência de Prebióticos Na Fermentação de Extrato Hidrossolúvel de Soja Verde. In: Anais do $12^{\circ}$ Congresso Latinoamericano de Microbiologia e Higiene de Alimentos - MICROAL 2014 [= Blucher Food Science Proceedings, num.1, vol.1]. São Paulo: Editora Blucher, 2014. 
pH do extrato de soja hidrossolúvel (controle) produzido com a variedade chinesa não atingiu pH 4,8 após 6 h de fermentação, estabilizando em 5,1 \pm 0,1. A adição de FOS ou inulina reduziu o tempo de fermentação para $5 \mathrm{~h}$, entretanto em 29 dias de armazenamento a contagem de S. thermophilus era $1 \log$ menor em comparação à bebida sem os prebióticos. A fermentação do extrato de soja produzido com a variedade BRS 232 ocorreu em 4 h, e a adição de FOS neste extrato não influenciou o tempo de fermentação. A contagem de L. acidophilus e Bifidobacterium permaneceu acima de $10^{6}$ e $10^{7} \mathrm{UFC} / \mathrm{mL}$, respectivamente, durante 29 dias de armazenamento, em todas as bebidas fermentadas avaliadas. O extrato de soja verde mostrou ser um meio adequado para a fermentação e sobrevivência de bactérias probióticas e $\mathrm{S}$. thermophilus, entretanto a influência de frutanos na velocidade de fermentação depende da variedade do grão de soja.

Palavras-Chave: soja verde, probióticos, prebióticos Agência de Fomento: FAPESP 